\title{
Inhibition of muscle differentiation by the adenovirus E1a protein: repression of the transcriptional activating function of the HLH protein Myf-5
}

\author{
Thomas Braun, Eva Bober, and Hans Henning Arnold ${ }^{1}$ \\ Department of Toxicology, Medical School, University of Hamburg, 2000 Hamburg 13, Germany
}

\begin{abstract}
Myogenic differentiation can be inhibited by the adenovirus E1a protein in the rat L6 muscle cell line. The present investigation provides evidence that E1a interferes with the expression of myogenin and the activity of Myf-5, the two myogenic helix-loop-helix (HLH) proteins that are expressed in L6 muscle cells. In nuclei of E1a-expressing L6 cells, Myf-5 protein accumulates to normal or even elevated levels and shows no alterations of its ability to bind to the DNA-binding site (CANNTG). However, trans-activation of muscle-specific reporter genes by Myf-5 is strongly inhibited. The same inhibition by E1a can be shown for the other myogenic HLH proteins, MyoD, myogenin, and MRF4/Myf-6, that have been expressed in 10T1/2 fibroblasts. In contrast to the normal level of Myf-5 expression, synthesis of myogenin is entirely abolished in the differentiation-defective L6-E1a cells. Here, we demonstrate that the carboxy-terminal trans-activator domain and probably the basic-HLH (bHLH) region of Myf-5 constitute targets for the inhibition by E1a. The effect of E1a depends on its intact transforming regions but not on the transcriptional activator domain. Our data suggest that activation of myogenin gene expression and the establishment of the differentiated phenotype may require functional Myf-5. Expression of the Myf-5 gene, however, is apparently independent of auto- or cross-regulation by the myogenic HLH proteins.
\end{abstract}

[Key Words: Myogenic differentiation; adenovirus Ela protein; L6 rat muscle cells; transcriptional activation]

Received November 21, 1991; revised version accepted February 20, 1992.

The identification of the muscle-specific helix-loop-helix (HLH) proteins MyoD1 (Davis et al. 1987), myogenin/ Myf-4 (Braun et al. 1989a; Edmondson and Olson 1989; Wright et al. 1989), Myf-5 (Braun et al. 1989b); and MRF4/herculin/Myf-6 (Rhodes and Konieczny 1989; Braun et al. 1990a; Miner and Wold 1990 provides a framework for the investigation of the complex control mechanisms underlying the development of skeletal muscle. The forced expression of each of these proteins has been shown to be sufficient to convert $10 \mathrm{~T} 1 / 2$ mouse fibroblasts to the myogenic lineage and to activate the muscle differentiation program (Davis et al. 1987; Tapscott et al. 1988; Braun et al. 1989a,b, 1990a; Edmondson and Olson 1989; Wright et al. 1989). The involvement of muscle HLH genes in organogenesis of skeletal muscle in vivo is inferred from their specific spatiotcmporal developmental pattern of expression. During mouse embryogenesis, each of the HLH genes exhibits a distinct, individual expression profile that is restricted to developing skeletal musculature and its progenitor cells (Sassoon et al. 1989; Bober et al. 1991; Ott et al. 1991).

\footnotetext{
${ }^{1}$ Corresponding author.
}

The transient expression of Myf-5 precedes that of myogenin and the other myogenic control genes, suggesting that it may act upstream and control the activation of these genes (Ott et al. 1991).

The myogenic regulatory factors share extensive sequence homology within a basic region and a putative $\mathrm{HLH}$ domain, which are required for DNA binding and protein dimerization, respectively (Murre et al. 1989a,b; Brennan and Olson 1990; Davis et al. 1990|. They recognize and bind the DNA consensus sequence CANNTG that is present in regulatory elements of many musclespecific genes and has been shown to be an essential sequence element for the tissue-specific transcription of muscle creatine kinase (MCK) (Sternberg et al. 1988; Buskin and Hauschka 1989|, myosin light chain 1/3 (Donoghue et al. 1988; Rosenthal et al. 1990), $\alpha$-cardiac actin (Sartorelli et al. 1990), and the $\alpha$-subunit of the acetylcholine receptor (Piette et al. 1990). Reporter genes containing this DNA consensus motif, known as E box, can be activated transcriptionally in nonmuscle cells by the expression of muscle $\mathrm{HLH}$ proteins (Braun et al. 1990a,b; Rosenthal et al. 1990; Yutzey et al. 1990). For the Myf-5 molecule we have identified a transcriptional activating region located carboxy-terminal to the bHLH 
domain, suggesting its function as a bona fide transcription factor (Braun et al. 1990b).

The molecular mechanisms that restrict the expression of the regulator proteins to muscle have not been defined. Moreover, it has not been possible to ascribe distinct functions to the individual regulatory proteins, largely because myogenic factors, when overexpressed in $10 \mathrm{~T} 1 / 2$ fibroblasts, not only autoactivate their corresponding endogenous genes but also cross-activate the expression of the other members of the gene family (Braun et al. 1989a; Thayer et al. 1989). Consequently, it has been difficult to clarify whether the four known muscle-determining proteins are part of a functional hierarchy or network, or whether they constitute functionally redundant gene products. As a strategy to circumvent some of these problems we have used inhibitors of myogenesis in muscle cell lines and studied the consequences of their action on the expression and activity of muscle-specific regulators. In this investigation we used the adenovirus AdEla protein, which has been shown to suppress myogenic differentiation and to inhibit transcription from muscle-specific promoters in L8 and C2 muscle cells (Webster et al. 1988; Enkemann et al. 1990).

The natural function of AdEla is to control the expression of viral and cellular genes. These biological activities involve three regions of the protein that are highly conserved among Ela proteins from different adenoviruses (for review, sce Moran and Matthews 1987). The conserved region 3 (CR3) is necessary and sufficient to stimulate transcription of carly viral genes (for review, see Flint and Shenk 1990). It does so by modulating the activity of cell-encoded transcription factors /Hoeffler et al. 1988; Jones et al. 1988; Simon et al. 1988; Raychaudhuri et al. 1989; Yee et al. 1989) by use of the activator domain as an adaptor to allow interaction with the basic transcriptional machinery (Martin et al. 1990). Conserved regions 1 and 2 (CR1 and CR2, respectively) are required for immortalization of primary cells and cellular transformation (Lillie et al. 1986, 1987; Moran et al. 1986; Zerler et al. 1986; Schneider et al. 1987; Subramanian et al. 1988; Whyte et al. 1988). In addition, E1a represses certain viral and cellular gene activities (Borelli et al. 1984; Hen et al. 1985; Velcich et al. 1986; Stein and Ziff 1987; Reich et al. 1988; Timmers et al. 1989), particularly that of members of the metalloprotease family such as stromelysin and collagenase types I and IV /Garbisa et al. 1987; Offringa et al. 1988). The down-regulation of these genes by Ela involves the repression of AP- 1 activity and requires the transforming region CR1 (Offringa et al. 1990). Very little is known, however, as to how the Ela oncogene product is able to selectively suppress cell type-specific functions without inhibiting housekeeping functions.

Here, we report that Ela represses myogenic differentiation in L 6 muscle cells by inactivating the musclespecific HLH proteins Myf-5 and myogenin. We show that Ela specifically inhibits the trans-activator function of Myf-5 and the transcription of myogenin. Ela does not interfere with the synthesis of Myf-5 or with its ability to bind to DNA. The inhibitory effect is independent of the activating domain of E1a located in CR3 but strongly depends on the intact CR1 that is essential for the transforming activity of E1a (Lillie et al. 1986, 1987; Schneider et al. 1987). The inactivation of Myf-5 protein in L6 cells and the parallel loss of myogenin synthesis suggests that active Myf-5 may be required for the transcription of the myogenin gene.

\section{Results \\ Expression of myogenin but not Myf-5 is prevented in E1a-expressing L6 muscle cells}

To investigate the mechanism by which Ela may lead to the loss of the myogenic phenotype in established muscle cell lines (Webster et al. 1988), we have transfected L6 muscle cells with plasmids expressing the wild-type Ela 13S mRNA from its own or the Rous sarcoma virus long terminal repeat (RSV LTR) promoter. Approximately 40 stably transfected clones were isolated and inspected for their myogenic capacity under growth conditions that induce differentiation and fusion in control L6 cells. None of the Ela transfected clones showed signs of myotube formation, but they retained the morphology and behavior of mononucleated, normally dividing myoblasts (data not shown). Normal L6 myocytes express the muscle regulatory factors Myf-5 and myogenin but no MyoD1 (Braun et al. 1989a; Wright et al. 1989). Assuming that both gene products are required and responsible for generating and maintaining the muscle phenotype in L6 cells, we reasoned that these proteins constitute potential targets for the inhibitory effect of Ela. To analyze the synthesis of Myf-5 and myogenin in E1a- expressing L6 cells, individual clones were expanded and RNA was isolated. Using RNA protection and Northern blot analysis, the Ela clones revealed normal or elevated levels of Myf-5 mRNA, whereas mRNA encoding myogenin was completely absent, even under culture conditions at which L6 cells normally differentiate and express high levels of myogenin mRNA (Fig. 1). This result was confirmed by immunohistochemical staining with specific antibodies to Myf-5 and myogenin, which showed normal accumulation of Myf -5 protein in nuclei of Ela-expressing cells but no myogenin /data not shown). From these results we conclude that Ela leads to a block of myogenin expression but does not affect the transcription of the Myf-5 gene, suggesting that both genes are regulated by independent mechanisms.

\section{E1 a does not alter the DNA-binding capacity of Myf-5}

Transcription of the myogenin gene is restricted to muscle cells and can be induced in nonmuscle cells by the coexpression of muscle-specific HLH proteins such as Myf-5 (Salminen et al. 1991). During mouse development, a transient burst of Myf- 5 expression precedes the activation of the myogenin gene in early somites and limb buds (Bober et al. 1991; Ott et al. 1991). Thus, it is 
Figure 1. Ela-expressing L6 muscle cells contain normal levels of Myf- 5 mRNA but no myogenin mRNA. RNA isolated from individual L6-Ela clones and growing $|\mathrm{g}|$ or differentiating (d) L6 and C2 control cells was analyzed by S1 nuclease protection using a Myf5-specific DNA probe $\{A \mid$ and on Northern blots using hybridization probes for myogenin and GAPDH $|B|$. Details on the probes, labeling, and hybridization conditions are described in Materials and methods. Total cellular RNA 140 and $25 \mu \mathrm{g}$ i was used for $\$ 1$ and Northern blot analysis, respectively. Gel loading was controlled by staining of rRNA with ethidium bromide.
A

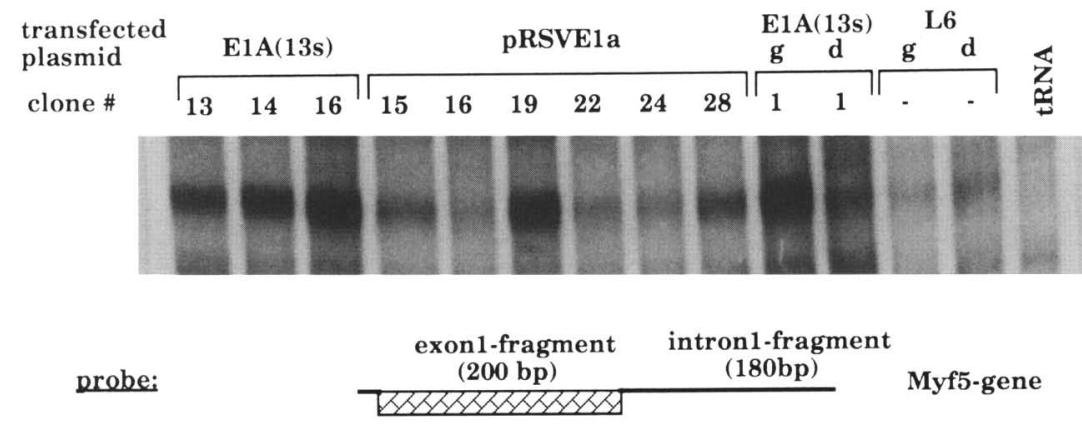

protected fragment:

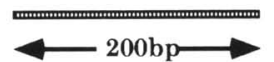

B

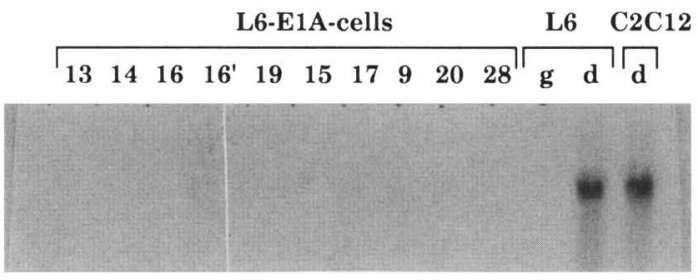

myogenin

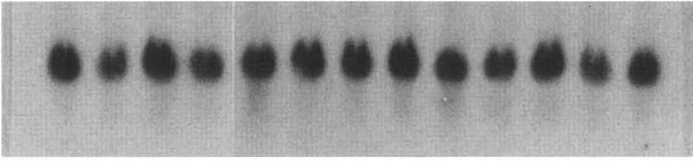

GAPDH

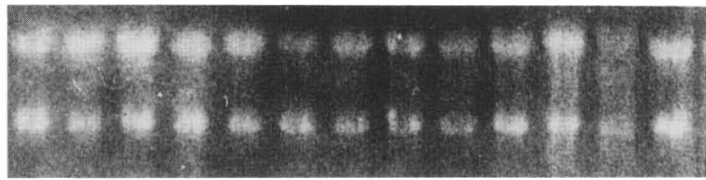

rRNA

lated $\mathrm{HLH}$ protein as they were shifted at least partially by antiserum to E12 (Fig. 2A, lanes 4,8). In contrast, the nuclear extracts from Ela-expressing L6 cells only formed the Myf-5/E12 DNA complex but failed to show Myf-4/E12 binding in agreement with the expression pattern of both genes in these cells (Fig. 1). Myf-5/DNA binding was even more intense as in control L6 cells (Fig. $2 \mathrm{~A}$, lanes 3,7$)$. The specificity of the applied antibodies was tested with in vitro-synthesized proteins as illus trated in Figure 2B. Taken together, the DNA-binding experiments unequivocally demonstrate that Myf-5 binds to its DNA target sequence with high efficiency in the presence of Ela protein, either tested in an in vitro mixing experiment (data not shown) or in the context of the L6-E1a nuclear extracts. Furthermore, the experiments indicate that Myf-5 protein accumulates in the nuclei of L6 cell nuclei expressing E1a to high concentrations, whereas myogenin protein is absent under these conditions. 


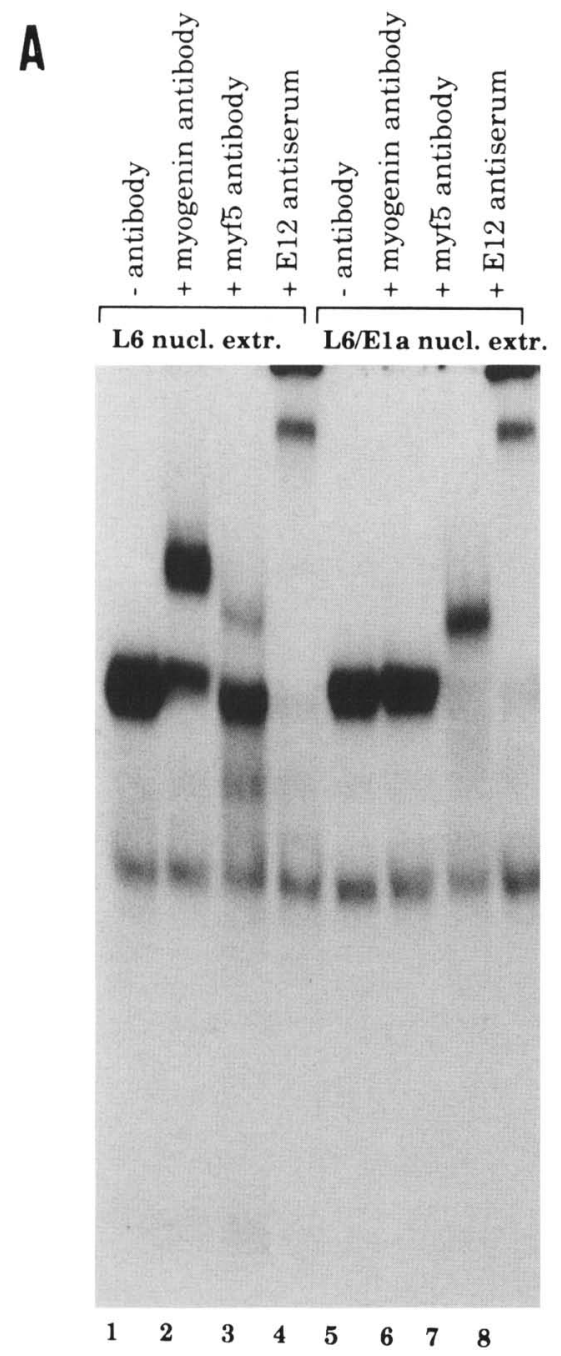

B

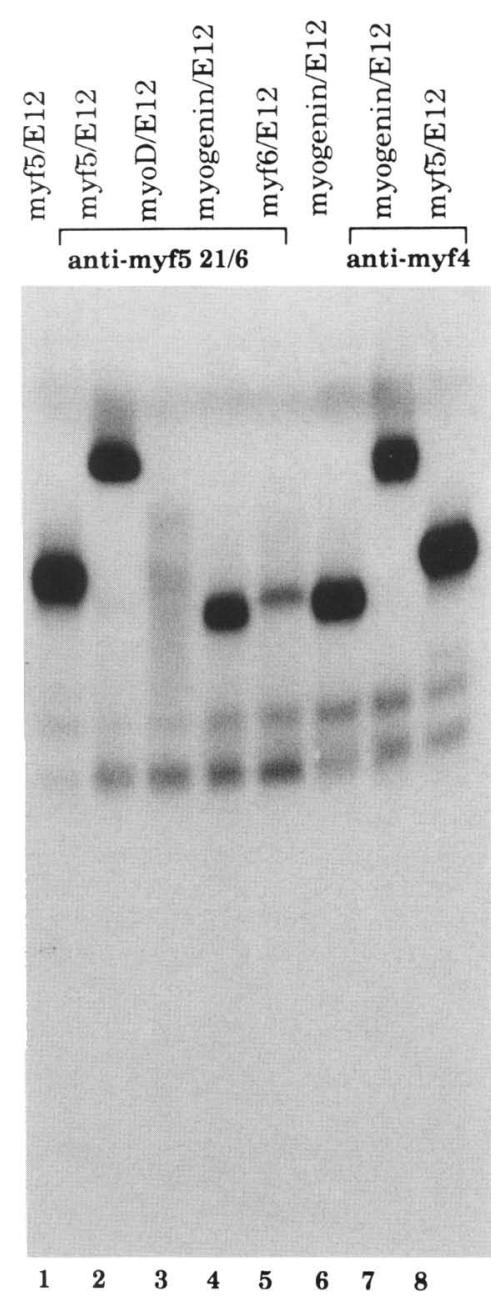

Figure 2. Myf-5 binds to DNA normally in the presence of Ela. $|A|$ Nuclear extracts of differentiated L6 muscle cells (lanes 1-4) and L6 cells expressing Ela (lanes 5-8) were tested in EMSA using the radiolabeled E-box oligonucleotide and antibodies to Myf-5 (lanes 3,7), myogenin (lanes 2,6), and E12 (lanes 4,8). (B) Determination of the specificity of the monoclonal antibody anti-myf5 $21 / 6$ and antimyogenin antibody with in vitro-translated Myf-5/E12 and myogenin/E12 proteins in EMSA. Note that anti-myf5 disrupts the MyoD/E12 complex, and reduces the intensity of Myf- 6 and myogenin complexes but does not supershift these antigenes.

\section{E1a inhibits the trans-activation by myogenic HLH proteins}

The possibility that Ela may inhibit myogenesis by interference with transcriptional activation mediated by myogenic HLH proteins was first tested in 10T1/2 fibroblasts on the muscle-specific reporter construct MLC1emb-chloramphenicol acetyltransferase (CAT) and cotransfection of plasmids expressing the various muscle regulatory HLH proteins from the murine sarcoma virus (MSV) LTR promoter (Braun et al. 1990b). The constitutively expressed $\beta$-actin promoter was used as control for a nonmuscle-specific target. It should be mentioned that under the applied conditions Ela did not affect the expression of the trans-activator plasmids controlled by the viral promoter (data not shown). Figure 3 shows that MyoD, Myf-5, Myf-4 (myogenin), and Myf- 6 were capable of activating the MLClemb promoter in $10 \mathrm{~T} 1 / 2$ nonmuscle cells but failed to do so in the presence of Ela. Coexpression of Ela completely prevented the transcriptional activation of the muscle-specific promoter, whereas the constitutive $\beta$-actin promoter re- mained virtually unaffected (Fig. 3). Together with the fact that Ela did not impair the ability of the Myf-5 transcription complex to bind to DNA, this result argues for interference of Ela with the actual trans-activator function of these proteins.

The trans-activation domain of Myf-5 constitutes a specific target for the inhibition by E1a

As L6 myoblasts only express Myf-5, we first concentrated on the analysis of this protein. To investigate the specificity of the Ela inhibition on Myf-5 trans-activation activity in more detail, we constructed chimeric fusion proteins containing the GAL4 DNA-binding domain fused either to the complete Myf-5-coding region (GALmyf5) or the carboxy-terminal half [GALmyf5(135255)]. These constructs allow the determination of transcriptional activation by Myf-5 independent of its bHLH region, which mediates sequence-specific DNA binding. Transcriptional activation by these hybrid proteins was tested after transfection of $10 \mathrm{~T} 1 / 2$ fibroblasts with the 

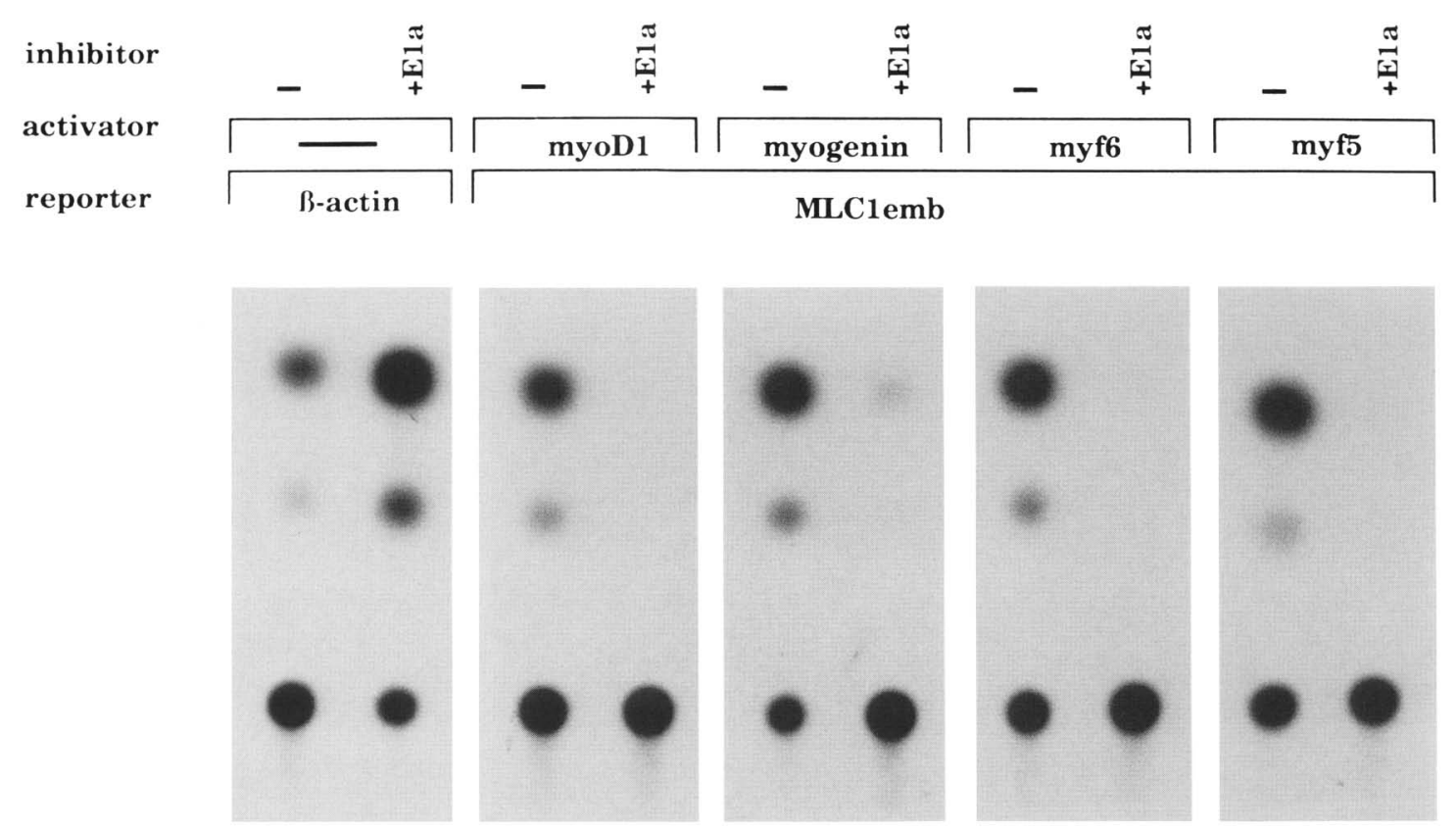

Figure 3. Trans-activation of the muscle-specific reporter gene MLClemb-CAT by myogenic HLH proteins is inhibited by the viral protein Ela. The reporter plasmid MLClemb-CAT $10 \mu \mathrm{g}$. Braun et al. 1990b) was transfected into $10 \mathrm{~T} 1 / 2$ fibroblasts together with plasmids expressing MyoDl, myogenin, Myf-5, or Myf- $6,5 \mu \mathrm{g}$ of pEMSV Myf vectors) and the expression vector RSVEla (5 $\mu \mathrm{g}$ ). The constitutive promoter of the $\beta$-actin gene driving CAT $\{10 \mu \mathrm{g}$ of P1-CAT; Lohse and Arnold 1988) was used as nonmuscle control. The slightly higher activity of $\mathrm{Myf}-4$ in this experiment does not reflect a statistically significant difference of the effect of Ela on the trans-activation by myogenin.

GAL4-CAT reporter containing five tandemly repeated GAL4-binding sites and plasmids expressing the GALmyf5 hybrid proteins. Activity was determined in the absence and presence of various concentrations of plasmids expressing Ela or VP16, which was used as a control. As shown in Figure 4, transcriptional activation by GALmyf5 (Fig. 4A) and GALmyf5|135-255' (Fig. 4B) was reduced by Ela in a concentration-dependent manner. Cotransfection of the Lex-VP16-expressing plasmid (contains LexA-binding domain to avoid interference with GAL4 binding) at similar concentrations had no inhibitory effect on either chimeric GAL4-Myf-5 protein (Fig. 4A,B). Likewise, trans-activations by GAL-VP16 (Fig. 4B) and the GAL4 wild-type protein (data not shown) were not affected by Ela.

To ascertain that the inhibition of GALmyf5 activity by Ela was not the result of reduced synthesis of the chimeric trans-activator proteins or to reduced DNA binding to the GAL4-binding site, we transfected COS cells (expressing large quantitics of the desired proteins) with GALmyf5 plasmids, together with either Ela or Lex-VP16 expression vectors. The GAL-E12-expressing plasmid was used as an additional control. Staining immunoblots of the nuclear extracts with antibodies to GAL4 protein revealed that similar concentrations of GALmyf5 and GAL-E12 trans-activator proteins accumulated in the absence and presence of Ela or Lex-VP16 (Fig. 5A). When the same nuclear extracts and those of cells transfected with control vectors [pKS, GAL4|1-
147)] were analyzed for binding to the GAL4 DNA-binding site, gel mobility-shift assays showed virtually no difference in complex formation whether or not E1a or Lex-VP16 proteins were present (Fig. 5B). Therefore, this indicates that the amount of GAL4-Myf- 5 chimeric proteins accumulating in the nucleus and the ability to bind to DNA remain unaffected by the simultaneous expression of Ela.

A conclusion from the results described so far is that Ela specifically inhibits the trans-activator function of Myf- 5 as neither the synthesis nor the DNA-binding capacity of Myf-5 is altered (Figs. 1 and 2). By analogy, one might assume that the same mechanism that leads to the inhibition of Myf-5 may also be responsible for the inhibition of the other muscle-specific HLH proteins (Fig. 3). Ela repression, however, is not a general phenomenon of transcription as the expression of the constitutive $\beta$-actin promoter and the trans-activator VP16 (Fig.4) are not affected. In contrast to Ela, the strong trans-activator VPl6 used as control shows no effect on GALmyf5 trans-activation at relatively high concentrations.

The ubiquitous HLH protein E12 is not inhibited by E1a

Active transcription complexes of myogenic HLH proteins require dimerization with more widely expressed 


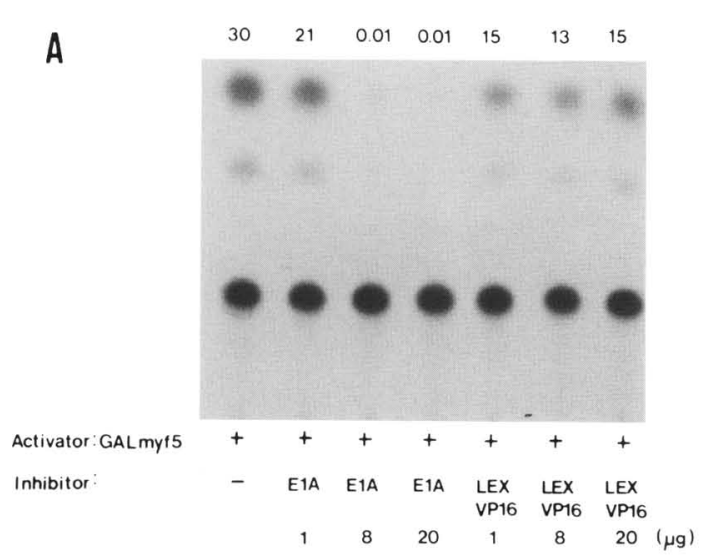

Figure 4. El a specifically obliterates the trans-activation mediated by the carboxy-terminal portion of the Myf-5 molecule. The trans-activator plasmids (1 $\mu \mathrm{g})$ GALmyf5 $\{A\}$, GALmyf5(135-255) (B), and $0.05 \mu \mathrm{g}$ of GAL-VP16 (B) expressing chimeric proteins containing the GAL4 DNA-binding site and various trans-activating domains, or $1 \mu \mathrm{g}$ of control plasmid GAL4(1-147) $(B)$ were cotransfected with the reporter plasmid $\mathrm{G}_{5} \mathrm{E} 1 \mathrm{~b}-\mathrm{CAT}(\mathrm{l} \mu \mathrm{g})$ in $10 \mathrm{~T} 1 / 2$ fibroblasts. Increasing concentrations of the vectors pl3S Ela or LexA-VPl6 were cotransfected as indicated. CAT activity was determined 2 days after transfection as described in $\mathrm{Ma}$ terials and methods. The percentage of substrate conversion is given above the chromatographs. One result representative of several experiments is shown. Schematic representation of the used plasmids is illustrated at the bottom. The numbers in parentheses indicate the amino acids encoded by the various constructs.
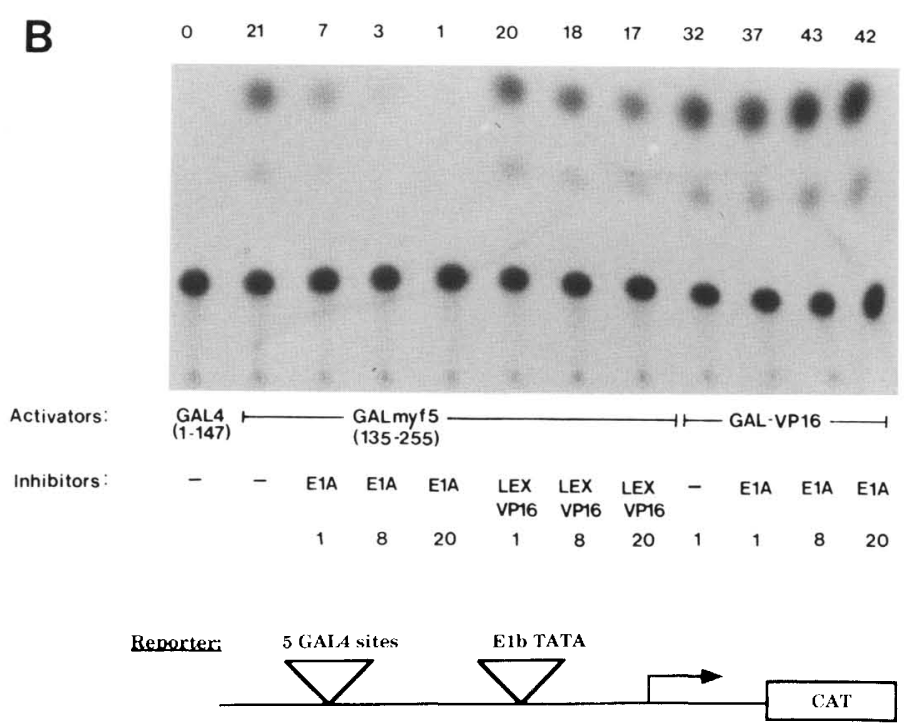

Activators:

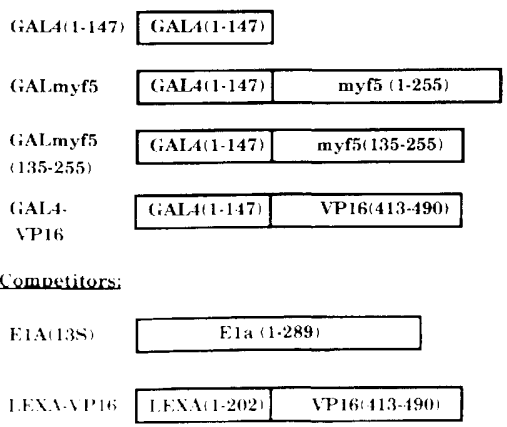

taining the trans-activating domain (Schneider et al. 1987; Offringa et al. 1990). As shown in Figure 7, after transfections with pRSV5Ela mCR3 carrying the inactivated CR3, the mutant protein reduced trans-activation by GALmyf5 with the same efficiency as wild-type Ela, indicating that no functional Ela trans-activating CR3 is required for the effect. In contrast, a mutation in the transforming CRI (pRSV5Ela mCR1) essentially abolished the inhibitory effect, although mCRl at much higher concentrations also showed moderate inhibition. The accumulation of mCR 1 in the nucleus was comparable to that of Ela wild type and the other Ela mutants (Offringa et al. 1990; data not shown). Mutated CR2 (pRSV5E la mCR2) appeared to be slightly less inhibitory than the wild-type Ela protein. We interpret these results as an indication that abolition of Myf- 5 trans-activating function by Ela may require the complete transforming part of the Ela molecule. Although CRl and CR2 perhaps coopcrate for the inhibition, the activating domain CR3 is virtually dispensable. Therefore, this strongly suggests that the inhibition by Ela is not the result of classical squelching, which probably would require CR3 to titrate out an activating component of the transcription complex (Ptashne 1988). To confirm the effects of the Ela mutants observed on the GALmyf5(135-255) chimera for the wild-type Myf-5 pro- 
A
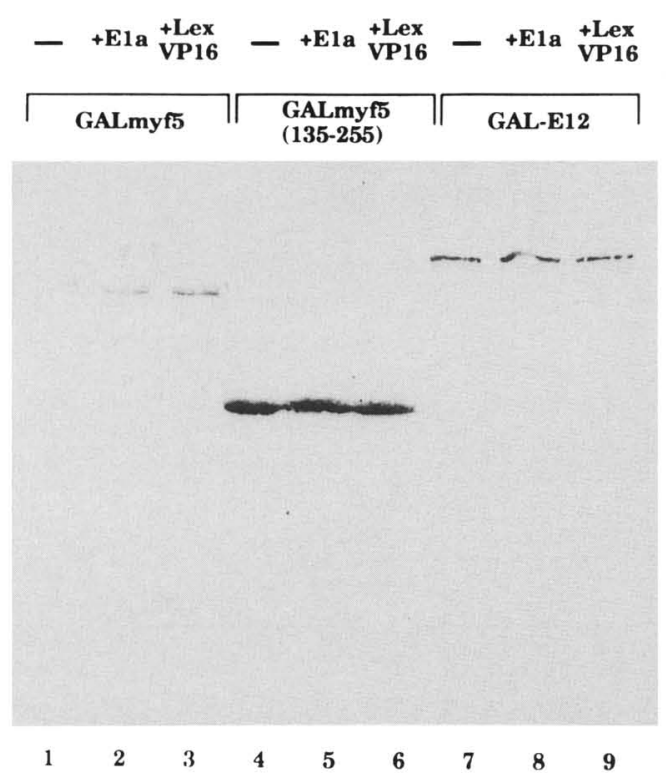

B

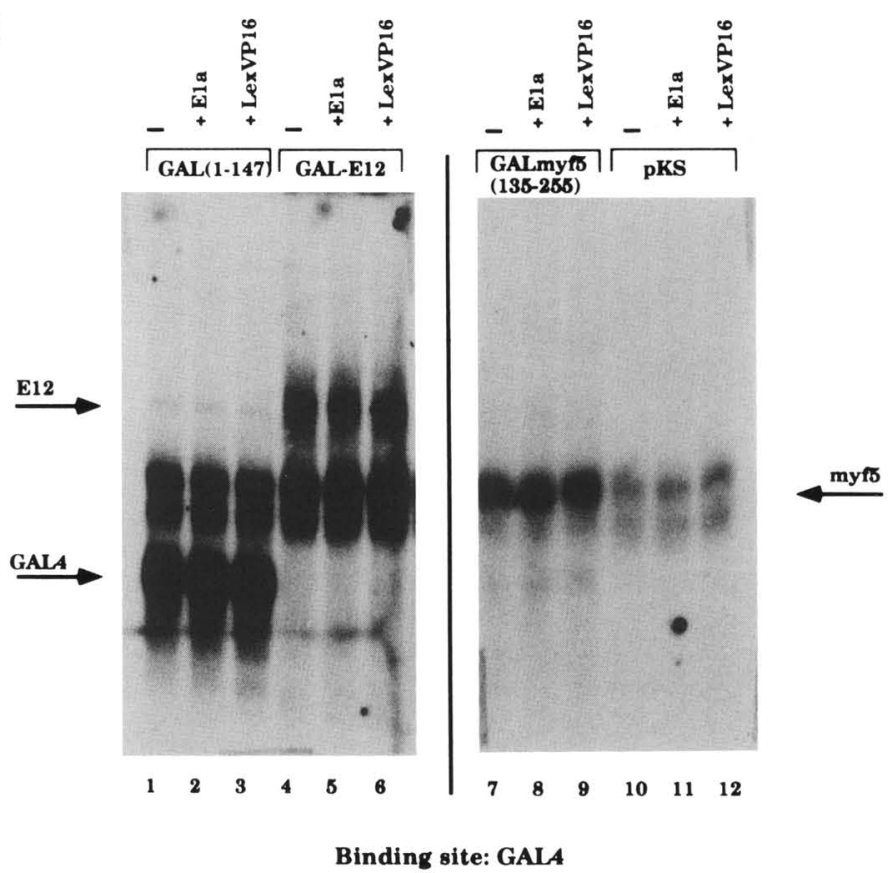

Figure 5. Synthesis of GALmyf5 hybrid proteins and their capacity to bind to DNA is unaffected by transient expression of Ela and VP16. COS cells were transfected with the expression vectors GALmyf5 $(2 \mu \mathrm{g})$ GALmyf5 $(135-255),(2 \mu \mathrm{g})$ and GAL-E12 (2 $\mu \mathrm{g})$ and 15 $\mu \mathrm{g}$ of vectors expressing $135 \mathrm{E}$ la or Lex-VP16. (A) Nuclear extracts, prepared as described in Materials and methods, were analyzed on immunoblots using an antibody against CrAL4 protein. The various fusion proteins were visualized using the Vectastain ABC kit. (B) EMSAs were performed with nuclear extracts of COS cells transiently transfected with vectors expressing GAL4(1-147) (lanes 1-3), GAL-E12 (lanes 4-6i, GALmyf5; 135-255) (lanes 7-9), and pKS control vector lanes 10-12), together with expression plasmids for 13S Ela or Lex-VP16. The synthetic oligonucleotide AGCTCTAGAAGTCGGAGTACTGTCCTCCGACT representing the GAL4-binding site was used for binding. Complexes containing CAL4, E12, and Myf-5 proteins are indicated by arrows. Note that the Myf-5 complex comigrates lanes $7-9\}$ with one of the background complexes $\{$ lanes $10-12\}$.

tein, we performed trans-activation experiments in 10T1/2 fibroblasts using Myf-4L-CAT plasmid containing the human muscle-specific Myf-4 (myogenin| promoter as reporter gene and pEMSV-Myf-5 as trans-activator. As shown in Figure 8, cotransfection of either pRSV5E1a wt, pRSV5E1a mCR2, or pRSV5Ela mCR3 resulted in strong inhibition of trans-activation, whereas cotransfection of pRSV5E1 a mCR1 had no or only a marginal effect even at very high concentrations of pRSV5Ela mCRl plasmid. Cotransfection of Lex-Ela expressing only the trans-activator domain CR3 also did not inhibit the activity of Myf-5 wild-type protein. These results then ascertain that the Ela mutations affect transcriptional activation by wild-type Myf-5 in the same way as the GALmyf5 hybrid proteins.

The carboxy-terminal trans-activator domain of Myf-5 is not the only target for E1a

Previous studies on MyoDl and myogenin (Davis et al. 1990; Brennan et al. 1991; Weintraub et al. 1991! have shown that the basic regions of these transcription factors performed a critical role in trans-activation of muscle-specific genes in addition to their function in DNA binding. Moreover, both myogenic factors contain trans- activating domains in their amino termini (Brennan et al. 1991; Weintraub et al. 1991). Similar results have been obtained recently for Myf-5 (Winter et al. 1992). To test the effect of Ela on these other functional regions, we replaced the Myf- 5 carboxy-terminal activator region by the Ela-insensitive activator domain of VP16 (Martin et al. 1990; this paper). This Myf-5-VP16 hybrid protein maintains the DNA-binding properties of Myf-5. In fact, Myf-5-VP16 expressed in 10T1/2 cells was a strong activator of the endogenous myosin heavy-chain (MHC) gene (Fig. 9A) and the muscle-specific reporter plasmids Myf-4L-CAT containing the human myogenin promoter and MCK4R-CAT containing a tetrameric minimal E box (Fig. 9B). In the presence of Ela, however, both the activation of the myosin gene in 10T1/2 cells and the activation of the myogenin promoter were markedly inhibited, whereas the artificial minimal enhancer of MCK4R-CAT was not (Fig. 9A,B). Moreover, stable expression of Myf-5-VP16 in L6-E1a cells failed to induce the muscle phenotype (data not shown). From these results, we conclude that E1a also affects other targets in addition to the carboxy-terminal activator domain of Myf-5. As trans-activation by the Myf- 5 amino terminus alone is not inhibited by Ela (T. Braun et al., unpubl.), the bHLH region probably constitutes a second site for the action of Ela. 

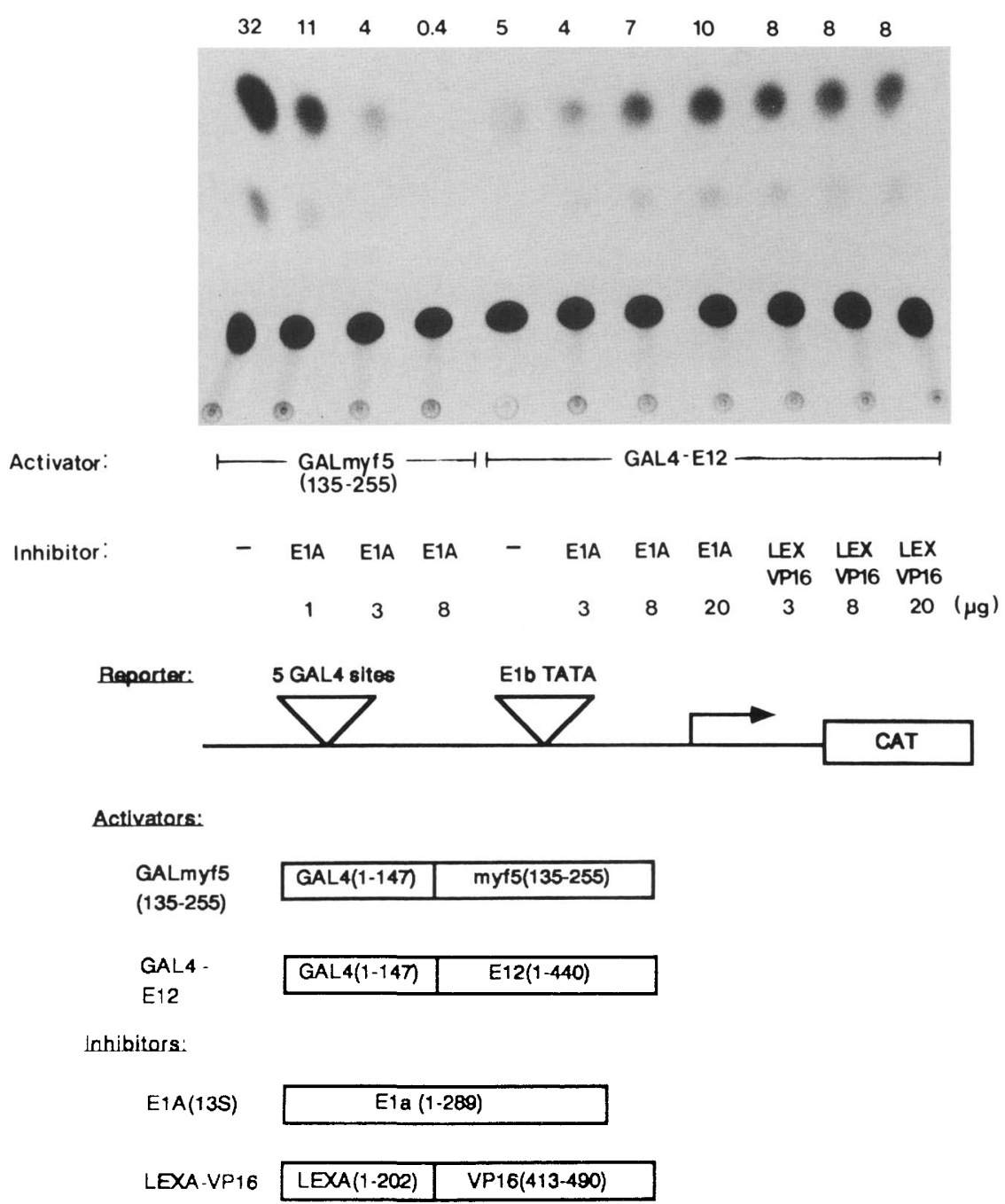

Figure 6. Trans-activation mediated by the HLH protein E12 is not inhibited by Ela and VP16. 10T1/2 fibroblasts were cotransfected with the chimeric activator plasmids GALmyf5(135-255) $(1 \mu \mathrm{gg})$ or GAL-E12 $(1 \mu \mathrm{g})$ together with increasing amounts of expression vectors for $13 \mathrm{~S} \mathrm{Ela}$ and VP16. Activation of the reporter construct $\mathrm{G}_{5} \mathrm{E} 1 \mathrm{~b}-\mathrm{CAT}(1 \mu \mathrm{g})$ was determined by standardized methods (see Materials and methods). All constructs used are outlined schematically at the bottom.

\section{Discussion \\ Muscle-specific transcription factors are targets for E1a inhibition}

The suppression of muscle differentiation by adenovirus Ela products has been documented previously (Webster et al. 1988; Enkemann et al. 1990|. In this report we show that Ela represses trans-activation of a musclespecific promoter mediated by each one of the four known myogenic HLH proteins, MyoD, myogenin, Myf5, and Myf-6 (Fig. 3). This inhibition is observed in cells transiently expressing Ela, which suggests that it is a direct effect rather than the result of cellular transformation. In L6 muscle cells stably expressing E1a, transcription of skeletal muscle marker genes stops completely (data not shown), which is presumably caused by the inactivation of the transcription factors Myf- 5 and myogenin (MyoD is not expressed in L6 cells). Myogenin mRNA does not accumulate in L6-Ela cells, which by itself could be the reason for the failure to differentiate. The inactivation of Myf-5 is not so obvious as neither transcription of the gene nor the accumulation of the protein in the nucleus appears to be diminished. Myf- 5 protein that has been made in Ela-expressing L6 cells binds normally to its DNA recognition sequence CANNTG. This indicates that Ela does not interfere with the formation of the muscle-specific Myf-5 DNA transcription complex. Because inhibition of the Myf-5 trans-activator function cannot be determined directly in L6 cells, it was testcd in 10T1/2 fibroblasts using GALmyf5 fusion constructs that activate a GAL4 reporter gene. In this system CAT activity is dependent on GAL4-binding sites and a functional Myf-5 activator domain. We find that Ela prevents CAT activity without affecting DNA binding, which clearly demonstrates the interference of Ela with the Myf-5 trans-activator function. That the Ela inhibition occurs also on natural muscle-specific promoters that are activated by the wild-type Myf-5 protein was shown for the human MLClemb promoter (Fig. 3), the Myf-4 promoter (Fig. 8), and the endogenous MHC gene (Fig. 9A). The weak transcriptional activation exerted by the ubiquitous HLH protein E12 (part of the Myf-5 DNA-binding complex) is not subject to inhibition by E1a. On the basis of these results, it 
Figure 7. Transforming domain $\mathrm{CRl}$ of Ela is required for the abrogation of the trans-activator function of Myt-5. The $\mathrm{G}_{5} \mathrm{E} 1 \mathrm{~b}$ reporter plasmid $|\mathrm{I} \mu \mathrm{g}|$ was cotransfected into 10T1/2 fibroblasts with the activator plasmid GALmyf5 $(135-255)(1 \mu \mathrm{g})$ and two concentrations (1 and $3 \mu \mathrm{g}$ ) of plasmids expressing the various inhibitor proteins (shown schematically!. The percentage of chloramphenicol conversion is given at the top of each CAT assay. Only mCRl shows a drastic reduction in activity.

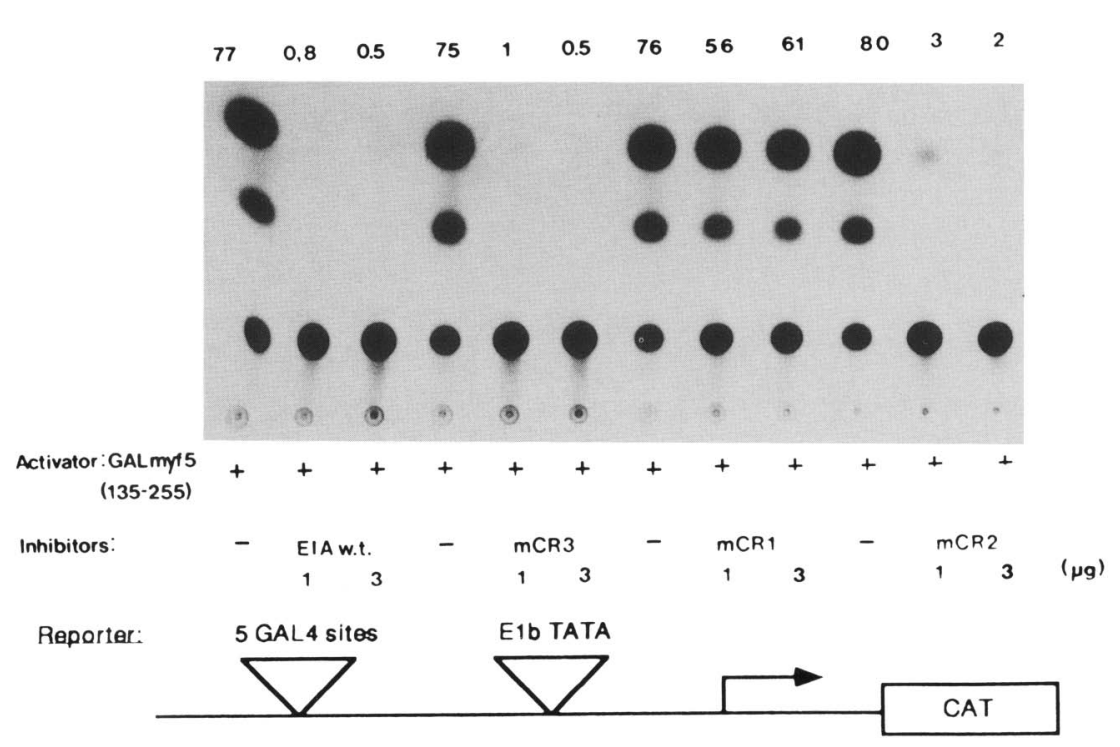

Activators:

GALmy 5

(135-255)

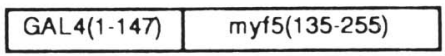

Inhibitors:

pRSV5E1awt

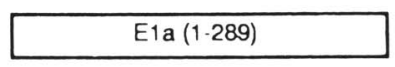

PRSV5E1a MCR1

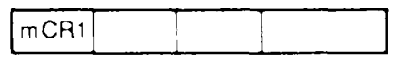

PRSVSE1a mCR2

mCR2

FRSV5E1a mCR3

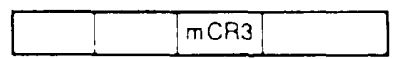

seems reasonable to assume that repression of myogenesis by Ela is mediated by the specific interference with the transcriptional activating regions of muscle HLH proteins. In L6 cells, the carboxy-terminal trans-activator region of Myf -5 appears to be a principal target but not the only one for Ela inhibition, as substitution of the Ela-sensitive Myf-5 carboxyl terminus by the Ela-insensitive VP16 activator domain does not restore normal myogenesis. The conserved bHLH region probably constitutes an additional Ela target that could explain why trans-activation by all four myogenic factors is inhibited by Ela. It is interesting to note that activation of the minimal enhancer MCK4R-CAT by Myf-5-VP16 is not inhibited by Ela, a situation that is reminiscent of MyoDl and myogenin basic region mutants, which also activate MCK4R-CAT but otherwise fail to trans-activate muscle-specific genes (Brennan et al. 1991; Weintraub et al. 1991). The muscle recognition code encoded by the basic region, which acts dependent on, but distinguishable from, DNA binding may conceivably be an additional site for interference by Ela, possibly by competition with an accessory protein or coactivator that normally bridges the basic and carboxy-terminal activator region. Studies to investigate the importance of the retinoblastoma gene product $(\mathrm{Rb})$ in this context are in progress.

The inhibition of transcriptional activation is a specific function of the transforming region of E1a

The notion that expression of E1 a CR3 alone does not transmit the inhibition to the Myf-5 activator is interesting because it may help to explain the mode by which Ela repression works. A mechanism based on competition with a component of the basic transcription machinery (squelching) seems very unlikely, as one would expect that this involves the Ela trans-activator domain CR3 (Martin ct al. 1990). Furthermore, a general mechanism should involve many genes and therefore have a detrimental effect on the viability of cells. We do not observe such an effect. On the contrary, Ela causes specific cellular alterations exhibited by the up-regulation of housekceping functions, such as metabolic enzymes (Kaddurah-Daouk et al. 1990), and the down-regulation of certain specialized functions associated with differentiation. Both of these activities seem to be important aspects of cell transformation exerted by the Ela oncogene. A mutation in CR1 of Ela drastically diminishes 


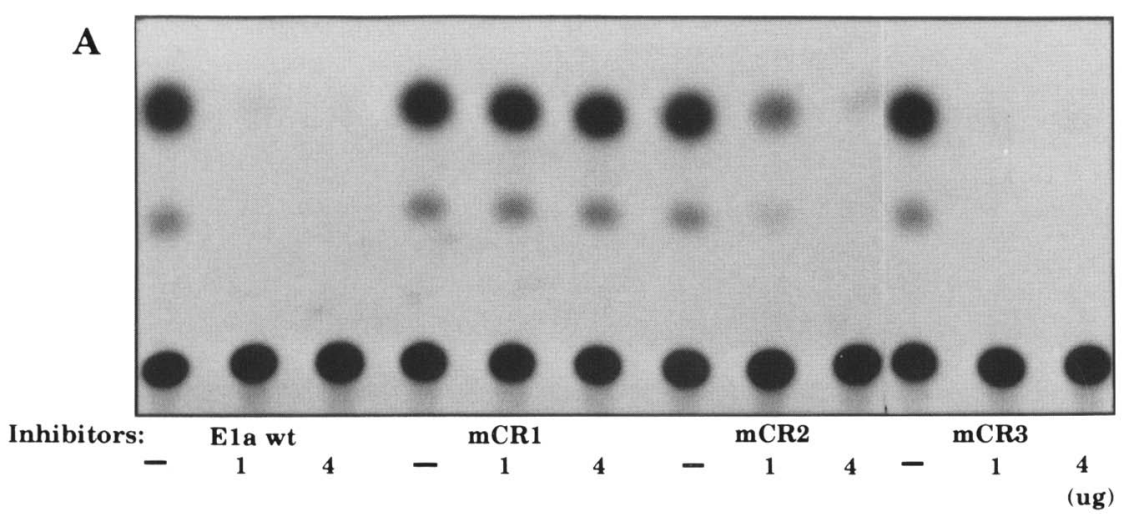

B
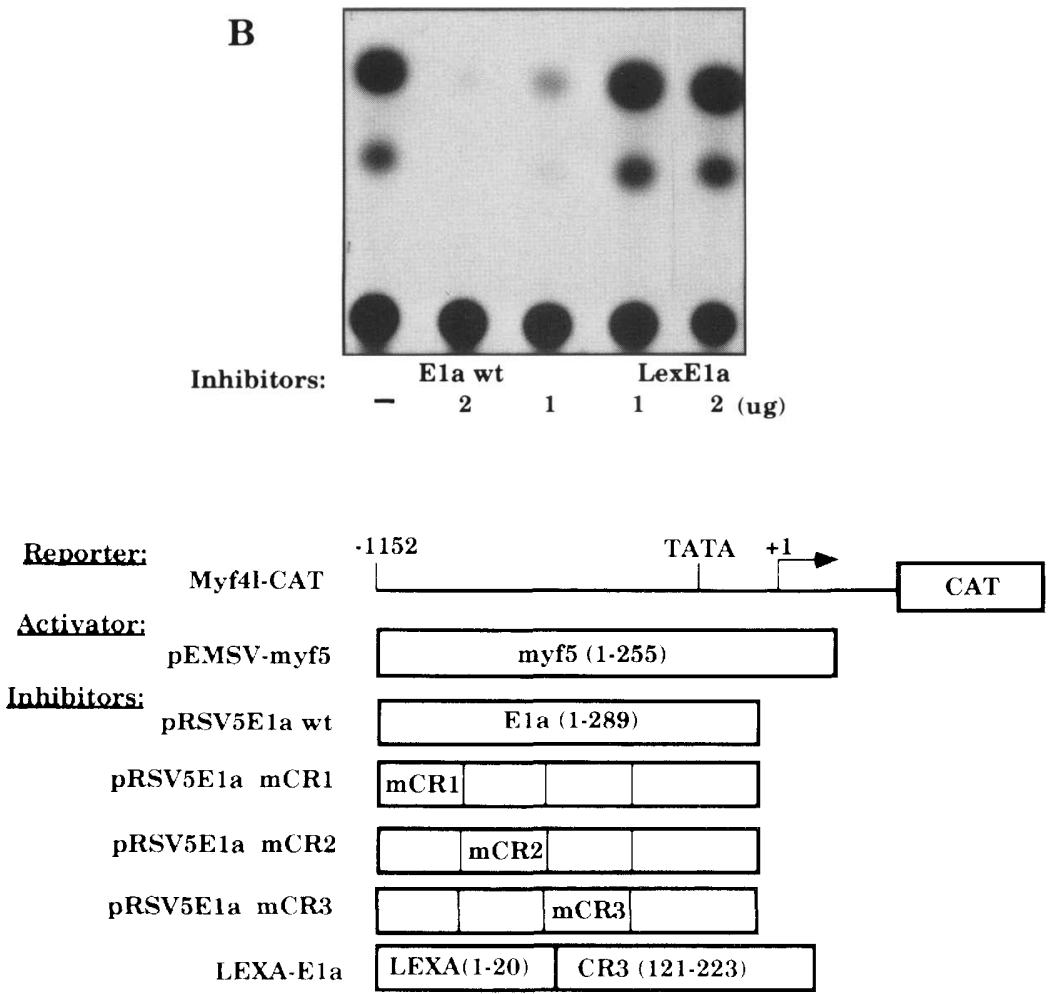

Figure 8. Effect of Ela mutations on the trans-activation of the Myf-4 promoter by wild-type Myf-5. The Myf-4L-CAT reporter plasmid $(8 \mu \mathrm{g})$ carrying the human myogenin promoter was cotransfected with activator plasmid pEMSV-Myf-5 18 $\mu \mathrm{g})$ and increasing concentrations $(2,8$, and $20 \mu \mathrm{g}$ ) of plasmids encoding the various Ela mutants $(A)$. Similar cotranfections were performed with plasmids expressing E1a wild-type $(0.5$ and $1 \mu \mathrm{g})$ and Ela CR3 (LEXE1al and $2 \mu \mathrm{g}$ ) (B). All plasmid constructs are indicated schematically. A representative result from three independently performed experiments is shown. its inhibitory activity on Myf-5. It should be mentioned, however, that high concentrations of pRSV5E1amCR1 also reduced trans-activation by $\mathrm{Myf}-5$. This indicates that in addition to $\mathrm{CR}$ l other regions of the protein may contribute to the inhibition. Interestingly, mutation of CR2 also reduces the efficiency slightly (Fig. 7). Alternatively, the mutation in CR1, although completely inactivating the transforming activity of Ela, may not suffice to totally abolish the inhibitory function on transcription. In any case, the requirement of CR1 but not CR3 for the repression of trans-activation ties this effect to the transforming activity of Ela and suggests that both biological activities may be related. Growth and differentiation are mutually cxclusive events in muscle cells. Therefore, the blockade of muscle differentiation by Ela may well be the primary step in transformation, allowing continued proliferation in response to growth signals. The inhibition of Myf- 5 activity by Ela resembles that described for AP-1, which also requires the transforming domain of E1a and is not mediated by alterations in AP-1 synthesis or DNA binding (Offringa et al. 1990). As shown by these investigators, down-modulation of AP-1 activity is not a general feature of dominant transforming oncogenes. Similarly, we find that Myf- 5 trans-activation is not down-regulated by other transforming proteins, such as Ha-ras and v-mos, and only marginally by v-fos (T. Braun, E. Bober, and H.H. Arnold, unpubl.). Because all of these oncogene products prevent muscle differentiation, they must do so by mechanisms different from those described here for E1a. It has been shown that inhibition of myogenesis by v-ras and v-fos is associated with and dependent on the loss of MyoDl and myogenin transcription and probably does not primarily involve inactivation of MyoD functions (Lassar et al. 1989|. The mechanism leading to the block in MyoD transcription has not been defined. 
A

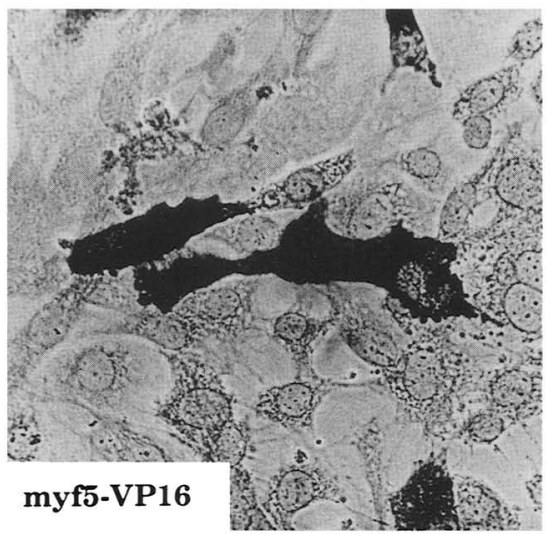

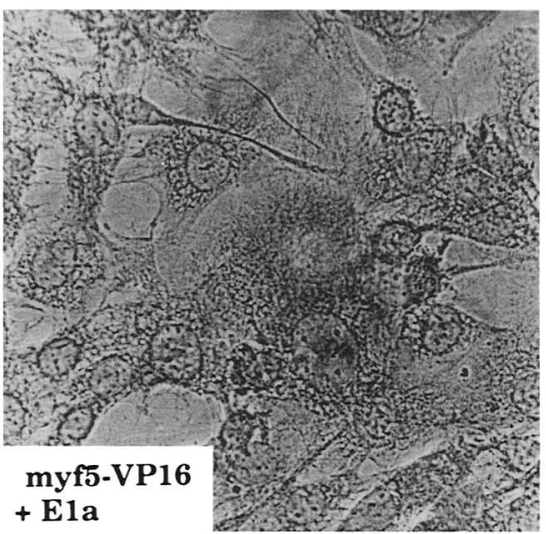

Figure 9. Expression of Myf-5-VP16 does not overcome the inhibition of myogenesis and trans-activation of muscle genes exerted by E1a. (A) 10T1/2 fibroblasts were immunostained with MF20 monoclonal antibody specifically recognizing sarcomeric MHC. Typical phase-contrast views of cells transiently transfected with plasmids expressing Myf-5-VP16 or Myf-5VP16 plus Ela are shown. The dark-staining cells express MHC. The background of MHC-positive cells in $10 \mathrm{Tl} / 2$ control cells and in 10Tl/2 colls expressing Ela was zero. (B) Trans-activation of Myj-4LCAT and MCK4R-CAT reporter genes in $10 \mathrm{~T} 1 / 2$ fibroblasts cotransfected with expression vectors for Myf-5-VP16 trans-activator and Ela $\mid$ RRSV5-Elal. Although trans-activation of the Myf-4 promoter is inhibited by Ela, that of the minimal promoter MCK4R-CAT is not.
B

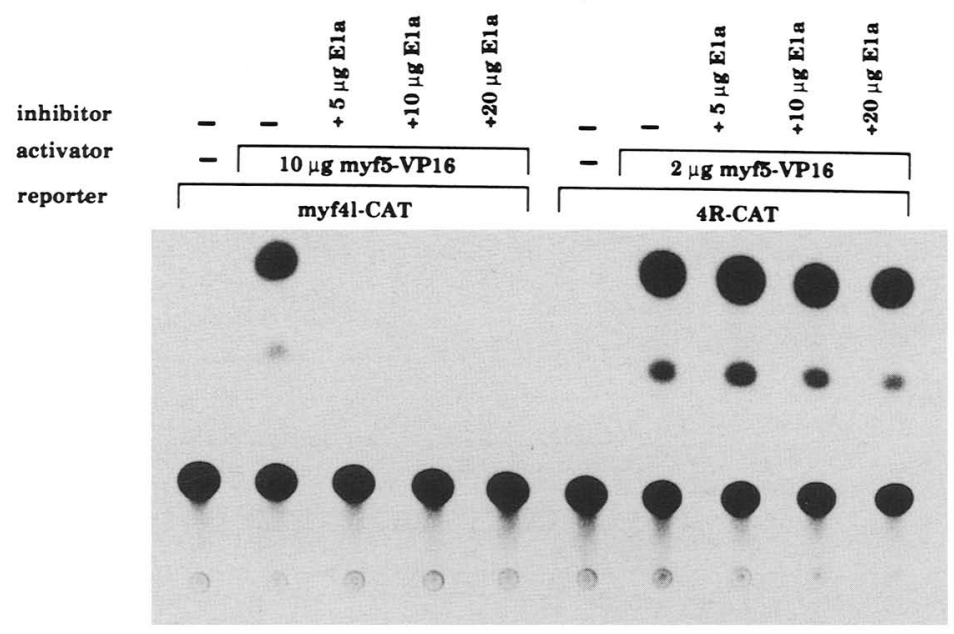

The repression of Myf- 5 activity by Ela could be caused either by post-translational modifications or could be mediated by protein-protein interactions. MyoDl and myogenin have been shown to be phosphoproteins (Tapscott et al. 1988; Brennan and Olson 1990); similar data have been obtained for Myf-5 (T. Braun et al., unpubl.l. Although we favor the possibility of a mechanism that is stoichiometric and not catalytic, as the repression by Ela appears to be concentration dependent, presently we have no indication for a direct interaction between Myf-5 and Ela or an Ela-induced protein. Our gel mobility-shift experiments, referred to in Figure 2, suggest that the Myf-5 DNA-binding complexes in nuclear extracts from control L6 and Ela-expressing $\mathrm{L} 6$ cells are identical.

\section{Modulation of Myf-5 activity may control myogenesis}

The observation that the trans-activator function of a tissue-specific transcription factor can be selectively repressed provides for a novel mechanism by which differ- entiation pathways may be controlled. It has been proposed previously that muscle differentiation critically depends on the level of the dominant repressor molecule Id, which prevents DNA binding of muscle HLH transcription complexes by interacting with the ubiquitous partner (Benezra et al. 1990). Although serum-controlled expression of Id may be one level to regulate the activity of myogenic HLH proteins, modulating the transcriptional activating function may be another. It has been reported that the nondifferentiating $\mathrm{C} 2$ cell derivative NFB (Peterson et al. 1990) lacks trans-activating capacity of the highly expressed Myf-5, although the level of Id is not elevated in this cell line. Similarly, some nonfibroblastic cell lines, which cannot be converted to the muscle phenotype by forced expression of a myogenic HLH protein, appear to exert a dominant-negative control that is distinct from Id (Weintraub et al. 1989; Schäfer et al. 1990). Ela provides an activity that could explain these various observations. It is interesting to note that F9 pluripotent stem cells contain an Ela-like activity that may be the cellular counterpart of the viral protein and 
may contribute to the repression of muscle $\mathrm{HLH}$ genes in these and other nonmuscle cells (Imperiale et al. 1984; La Thangue and Rigby 1987).

Although it is accepted by now that the skeletal muscle phenotype in vertebrates requires the presence of myogenic HLH proteins (for review, see Olson 1990), it is still unclear whether there is a functional hierarchy among the four known Myf proteins. In this report we show that Myf-5 is capable of activating transcription of the myogenin promoter and that inactivating Myf- 5 activity prevents the accumulation of myogenin mRNA in L6 cells. Whereas transcription of the Myf-5 gene continues in the absence of any active myogenic HLH protein, expression of myogenin appears to require active Myf-5. We interpret these results as an indication that the genes for Myf- 5 and myogenin are under different controls and that Myf-5 may act upstream of myogenin. This is compatible with and is supported by the temporal expression pattern of both genes during mouse development in which Myf-5 expression clearly precedes that of myogenin (Ott et al. 1991).

\section{Materials and methods}

\section{Cell culture and isolation of E1a-expressing L6 cell lines}

Rat L6 cells (Yaffe 1968) were obtained from the American Type Culture Collection (ATCC); C3H 10T1/2 cells were provided by H. Marquardt (University of Hamburg, Germany). All cells were grown as recommended by the ATCC, or in Dulbecco's modified Eagle medium (DMEM) containing 10\% fetal calf serum. Differentiation of the L6 cell line was generally induced by growth in DMEM supplemented with $10 \%$ horse serum for 8 days. Stable L6 cell lines expressing Ela were obtained by transfection of $\sim 1 \times 10^{5}$ cells with $1 \mu \mathrm{g}$ of $\mathrm{pKJ}$ lneo (Adra et al. 1987) and $30 \mu \mathrm{g}$ of RSV-Ela or 13sEla using the calcium phosphate precipitation procedure (Graham and van der Eb 1973). Selection of G418-resistant colonies was carried out as described previously (Braun et al. 1989a,b).

\section{Plasmids}

The plasmid Myf-4l-CAT was constructed by ligating a 1.2-kb $\mathrm{Ncol}$ fragment of the human myogenin gene encompassing $5^{\prime}$ upstream sequences, the promoter region, and the untranslated leader sequence (Salminen et al. 1991) in front of the CAT gene in plasmid pEMBL-CAT. The sequence of the promoter and its characterization are described elsewhere (Salminen et al. 1991).

The plasmids pGALmyf5, pGALmyf5(135-255), and GALE12 fusion genes expressing Myf-5, parts of Myf-5, or E12, respectively, have been described previously (Braun et al. 1990b). The reporter construct $\mathrm{G}_{5} \mathrm{E} 1 \mathrm{~b}-\mathrm{CAT}$ contains five GAL4-binding sites in front of the E1b TATA box (Martin et al. 1990). This plasmid and the eukaryotic expression plasmids pLexA-VP16, pGAL-VP16, and pLexEla, all driven by the SV40 early promoter and containing the DNA-binding domains of LexA or GAL4 proteins fused in-frame to the activation domains of VP16 (aa412-490) and Ela (aa121-223), respectively, have been kindly provided by M.R. Green (Harvard University, Boston, MA), and are described in detail by Martin et al. (1990). RSV Ad5Ela was given to us by A. van der Eb (University of Leiden, The Netherlands); the RSVAd5Ela mutants were originally described by Schneider et al. (1987) and recloned in RSVEla (Offringa et al. 1990). p13sE1a expressing the 289-amino-acid E1a from a fragment containing the Ela region of adenovirus type 5 without the $13 \mathrm{~S}$ intron has been described by Martin et al. (1990).

The expression plasmid Myf-5-VP16 was constructed from the EcoRI-NcoI fragment encoding amino acids 1-149 of Myf-5 fused in-frame to the VP16 activator domain obtained from plasmid pSG4-VP16 (supplied by M. Ptashne, Harvard University, Boston, MA). The combined fragment was inserted into the EcoRI site of pEMSV- $\alpha$ scribe.

\section{Trans-activation assays in transient transfections}

Transient CAT assays were performed in $10 \mathrm{~T} 1 / 2$ cells by transfecting $1 \mu \mathrm{g}$ of plasmids expressing the various GAL4 fusion derivatives as trans-activators along with $1 \mu \mathrm{g}$ of G5Ela-CAT reporter plasmid and $4 \mu \mathrm{g}$ of RSV- $\beta$-galactosidase plasmid as internal standard. The amount of cotransfected competitor DNA is indicated for each experiment. In the case of the human myogenin promoter, $8 \mu \mathrm{g}$ of Myf-4l-CAT was cotransfected with $7.5 \mu \mathrm{g}$ of pEMSVmyf5 and $5 \mu \mathrm{g}$ of RSV- $\beta$-gal plasmid as internal control. CAT activity was determined 3 days after transfections by standard methods in $10-30 \%$ of cellular ex tracts. Values were normalized to $\beta$-galactosidase activities to calibrate for different transfection efficiencies. The presented data are representative of at least three independently performed transfections for each experiment.

\section{Preparation of nuclear extracts from tissue culture cells}

To prepare nuclear extracts, $\sim 5 \times 10^{5}$ COS cells were transiently transfected with $2 \mu \mathrm{g}$ of the GALmyf 5 fusion constructs and $15 \mu \mathrm{g}$ of E1a or Lex-VP16 expression vectors. Cells were grown on $10-\mathrm{cm}$ dishes for 3 days, washed twice in phosphatebuffered saline (PBS), harvested by scraping with a rubber policeman, and pelleted in a microcentrifuge tube at $1400 \mathrm{rpm}$. The cells were resuspended in $0.4 \mathrm{ml}$ of $10 \mathrm{mM}$ HEPES $\{\mathrm{pH} 7.9\}$, $10 \mathrm{~mm} \mathrm{KCl}, 0.1 \mathrm{~mm}$ EDTA, 0.1 mM EGTA, $1 \mathrm{~mm}$ DTT containing $0.5 \mathrm{mM}$ PMSF, $1 \mu \mathrm{g} / \mu \mathrm{l}$ of leupeptin, $1 \mu \mathrm{g} / \mu \mathrm{l}$ of pepstatin, 1 $\mu \mathrm{g} / \mu \mathrm{l}$ of aprotinin, and $40 \mu \mathrm{g} / \mu \mathrm{l}$ of bestatin and were swollen on ice for $15 \mathrm{~min}$. Cells were lysed by NP-40 added to a final concentration of $0.7 \%$. The lysate was vortexed and centrifuged for $30 \mathrm{sec}$. The nuclear pellet was carefully resuspendend in $40 \mu \mathrm{l}$ of ice-cold $20 \mathrm{~mm}$ HEPES (pH 7.9), $0.4 \mathrm{M} \mathrm{NaCl}, 1 \mathrm{~mm}$ EDTA, $1 \mathrm{~mm}$ EGTA, $1 \mathrm{~mm}$ DTT, $0.5 \mathrm{~mm}$ PMSF, $1 \mu \mathrm{g} / \mu \mathrm{l}$ of leupeptin, $1 \mu \mathrm{g} / \mathrm{ml}$ of pepstatin, $1 \mu \mathrm{g} / \mu \mathrm{l}$ of aprotinin, and $40 \mu \mathrm{g} / \mu \mathrm{l}$ of bestatin. $\mathrm{Nu}-$ clei were extracted on a rotatory platform for $15 \mathrm{~min}$ at $4^{\circ} \mathrm{C}$. Insoluble material was removed by centrifugation for $10 \mathrm{~min}$ in a microcentrifuge, and the supernatant was stored in aliquots at $-80^{\circ} \mathrm{C}$.

To prepare nuclear extracts from L6 and Ela/L6 cells, 20 dishes $(10 \mathrm{~cm})$ were used and the procedure was scaled up accordingly. The supernatant was adjusted to $25 \mathrm{mM}$ HEPES (pH 7.91, $100 \mathrm{mM} \mathrm{NaCl}, 1 \mathrm{mM}$ DTT, $0.2 \mathrm{mM}$ EDTA, and $20 \%$ glycerol and loaded onto a small heparin-Sepharose column $\mid 0.5-\mathrm{ml}$ bed volume). The column was washed with loading buffer and eluted with the same buffer containing $0.8 \mathrm{M} \mathrm{NaCl}$. The eluate was dialyzed against $50 \mathrm{~mm}$ HEPES (pH 7.9), $50 \mathrm{~mm} \mathrm{NaCl}, 1 \mathrm{~mm}$ DTT, $0.2 \mathrm{mM}$ EDTA, and $10 \%$ glycerol and stored in aliquots at $-80^{\circ} \mathrm{C}$.

\section{Electrophoretic mobility-shift assay}

The binding reaction and gel-electrophoresis conditions used for electrophoretic mobility-shift assay (EMSA) have been described in Braun et al. (1990a). The Myf-5 DNA-binding site (MLC-enh) was derived from the human myosin light-chain en- 
hancer AGTAACAGCAGGTGCAAAATAAAGT /Rosenthal et al. 1990). Synthesis of oligonucleotides, purification, and labeling have been described previously (Braun et al. 1989c). Myf-4, Myf-5, and E12 proteins were synthesized from their corresponding mRNA templates generated from the linearized plasmid templates pT7myf5, pT7myf4, and pBS-ATG-E12 with T7 RNA polymerase. mRNA templates were translated in pretreated rabbit reticulocyte lysate (Promega) by standard procedures. Band shifts using nuclear extracts were usually performed with 4-20 $\mu \mathrm{g}$ of protein.

\section{Antibodies}

Mouse monoclonal antibodies against human Myf-5 were raised by the Hybridoma Laboratory at Institut Pasteur (Paris, France), using purified Myf-5-glutathione transferase fusion protein (Braun et al. 1990a). The detailed characterization of monoclonal antibodies to Myf-5 will be published elsewhere (H.H. Arnold, in prep.). The subclone anti-hmyf5 21.6 used here produces IgG2b globulin and was cultured as ascites to yield high titer.

Antiserum against E12 was raised in rabbits by injecting purified E12-glutathione transferase fusion protein. The fusion gene was constructed by inserting the E12 cDNA of plasmid pE12R (Murre et al. 1989a) into the bacterial expression vector pGEX (Smith and Johnson 1988). After three protein injections with complete and subsequently with incomplete Freund's adjuvant, rabbits were bled, the IgG fraction was precipitated from the serum with ammonium sulfate, and dialyzed against several changes of PBS before use in band-shift experiments. The mouse monoclonal antibody against rat myogenin was a kind gift of Woody R. Wright (University of Texas, Dallas). Rabbit antiserum against GAL4 protein was generously supplied by $M$. Ptashne.

\section{Western blot analysis and immunostaining}

For immunostaining with antiskeletal myosin antibody, MF20 cell cultures were washed extensively in PBS, fixed in $70 \%$ methanol and $30 \%$ acetone for $20 \mathrm{~min}$, and subsequently incubated overnight in $1: 5$ diluted MF20 supernatant at $4^{\circ} \mathrm{C}$. Unbound antibody was removed by washing with PBS, and the bound antibody was visualized using the Vectastain $A B C$ kit as suggested by the supplier.

Western blot analysis of nuclear extracts was performed with $\sim 30 \mu \mathrm{g}$ of nuclear proteins, separated on a $12 \%$ SDS-polyacrylamide gel, and transferred to nitrocellulose. The membrane was probed with antiserum against GAL4 protein. Enzyme-linked immunosorbent assays (ELISAs) were developed using the Vectastain $\mathrm{ABC}$ elite kit and $\mathrm{DAB}$ as a substrate in the presence of $\mathrm{Ni}_{2} \mathrm{Cl}$.

\section{RNA analysis from tissue culture cells}

Myogenin RNA was detected using a 700-bp probe from the $3^{\prime}$ end of the rat cDNA (Sassoon et al. 1989), which was labeled with $\left[{ }^{32} \mathrm{P}\right] \mathrm{dCTP}$ by random-priming (Amersham Kit). Isolation of RNA, gel electrophoresis, RNA transfer, and hybridization conditions have been described by Braun et al. (1989b). Myf- 5 RNA was detected by $\mathrm{S} 1$ analysis using a continuously labeled genomic DNA fragment of the mouse Myf-5 gene and $40 \mu \mathrm{g}$ of total cellular RNA from the various cell clones. A $380-b p$ HindIII fragment containing $200 \mathrm{bp}$ of exon 1 and $180 \mathrm{bp}$ of intron 1 of the Myf- 5 gene was cloned in M13mpl 8 to synthesize a continuously labeled, single-stranded probe. Probe purification, digestion with $\mathrm{S} 1$ nuclease, and analysis of the pro- tected fragment on a $6 \%$ polyacryamide gel containing $7 \mathrm{M}$ urea were done by standard protocols (Sambrook et al. 1989).

\section{Acknowledgments}

We thank M.R. Green and A. van der Eb for providing many of the plasmids used in this study. We thank M. Ptashne and W. Wright for valuable antibody reagents. We are grateful to $M$. Buckingham, J.C. Mazei, and F. Nato (Institut Pasteur, Paris, France) for assistance in the preparation of the monoclonal antibody to Myf-5. We gratefully acknowledge the skillful technical help of A. Lassen and B. Behrend and the secretarial work by A. Broecker-Nagel. We appreciate the friendly and critical review of the manuscript by $M$. Buckingham (Paris, France) and $E$. Olson (Houston, TX). This work was supported by Deutsche Forschungsgemeinschaft and the Deutsche Muskelschwundhilfe e.V.

The publication costs of this article were defrayed in part by payment of page charges. This article must therefore be hereby marked "advertisement" in accordance with 18 USC section 1734 solely to indicate this fact.

\section{References}

Adra, C.N., P.H. Boer, and M.W. McBurney. 1987. Cloning and expression of the mouse pGKl gene and the nucleotide sequence of its promoter. Gene 60: 65-74.

Benezra, R., R.L. Davis, D. Lockshon, D.L. Turner, and H. Weintraub. 1990. The protein Id: A negative regulator of helixloop-helix DNA binding proteins. Cell 61: 49-59.

Bober, E., G.E. Lyons, T. Braun, G. Cossu, M. Buckingham, and H.H. Arnold. 1991. The muscle regulatory gene myf6 has a biphasic pattern of expression during early mouse development. J. Cell. Biol. 113: 1255-1265.

Borelli, E., R. Hen, and P. Chambon. 1984. Adenovirus 2 Ela products repress enhancer-induced stimulation of transcription. Nature 312: 608-612.

Braun, T., E. Bober, G. Buschhausen-Denker, S. Kohtz, K.H. Grzeschik, and H.H. Arnold. 1989a. Differential expression of myogenic determination genes in muscle cells: Possible autoactivation by the Myf gene products. EMBO I. 8: 36173625.

Braun, T., G. Buschhausen-Denker, E. Bober, E. Tannich, H.H. Arnold. 1989b. A novel human muscle factor related to but distinct from $\mathrm{MyoDl}$ induces myogenic conversion in 10T1/2 fibroblasts. EMBO /. 8: 701-709.

Braun, T., E. Tannich, G. Buschhausen-Denker, and H.H. Arnold. 1989c. Promoter upstream elements of the chicken cardiac myosin light-chain 2-A gene interact with trans-acting regulatory factors for muscle-specific transcription. Mol. Cell. Biol. 9: 2513-2525.

Braun, T., E. Bober, B. Winter, N. Rosenthal, and H.H. Arnold. 1990a. Myf-6, a new member of the human gene family of myogenic determination factors: Evidence for a gene cluster on chromosome 12. EMBO J. 9: 821-831.

Braun, T., B. Winter, E. Bober, H.H. Amold. 1990b. Transcriptional activation domain of the muscle-specific gene-regulatory protein myf5. Nature 346: 663-665.

Brennan, T.J. and E.N. Olson. 1990. Myogenin resides in the nucleus and acquires high affinity for a conserved enhancer element on heterodimerization. Genes \& Dev. 4: 582-595.

Brennan, T.J., T. Chakraborty, and E. Olson. 1991. Mutagenesis of the myogenic basic region identifies an ancient protein motif critical for activation of myogenesis. Proc. Natl. Acad. Sci. 88: 5675-5679. 
Buskin, J.N. and S.D. Hauschka. 1989. Identification of a myocyte-specific nuclear factor which binds to the muscle-specific enhancer of the mouse muscle creatine kinase gene. Mol. Cell. Biol. 9: 2627-2640.

Davis, R.L., H. Weintraub, and A.B. Lassar. 1987. Expression of a single transfected cDNA converts fibroblasts to myoblasts. Cell 51: 987-1000.

Davis, R.L., P.-F. Cheng, A.B. Lassar, and H. Weintraub. 1990. The MyoD DNA binding domain contains a recognition code for muscle-specific gene activation. Cell 60: 733-746.

Donoghue, M., H. Ernst, B. Wentworth, B. Nadal-Ginard, and N. Rosenthal. 1988. A muscle-specific enhancer is located at the $3^{\prime}$ end of the myosin light-chain $1 / 3$ gene locus. Genes $\&$ Dev. 2: 1779-1790.

Edmondson, D.G. and E.N. Olson. 1989. A gene with homology to the myc similarity region of MyoDl is expressed during myogenesis and is sufficient to activate the muscle differentiation program. Genes Dev. 3: 628-640.

Enkemann, S.A., S.F. Konieczny, and E.J. Taparowsky. 1990. Adenovirus 5 Ela represses muscle-specific enhancers and inhibits expression of the myogenic regulatory factors genes, MyoD1 and myogenin. Cell. Growth Differ. 1: 375-382.

Flint, J. and T. Shenk. 1990. Adenovirus Ela protein, a paradigm viral trans-activator. Annu. Rev. Genet. 23: 141-161.

Garbisa, S., R. Pozzatti, R.J. Muschel, U. Saffiotti, M. Ballin, R.H. Goldfarb, G. Khoury, and L.A. Liotta. 1987. Secretion of type IV collagenolytic protease and metastatic phenotype by transfection with c-Ha-ras but not c-Ha-ras plus Ad2-E1a. Cancer Res. 47: 1523-1528.

Graham, F.L., and A.J. van der Eb. 1973. A new technique for the assay of infectivity of human adenovirus DNA. Virology 52: 456-467.

Hen, R., E. Borrelli, and P. Chambon. 1985. Repression of the immunoglobulin heavy chain enhancer by the adenovirus-2 ElA products. Science 230: 1391-1394.

Henthorn, P., M. Kiledjian, and T. Kadesch. 1990. Two distinct transcription factors that bind the immunoglobulin enhancer uE5/kE2 motif. Science 247: 467-470.

Hoeffler, W.K., R. Kovelman, and R.G. Roeder. 1988. Activation of transcription factor IIIC by the adenovirus Ela protein. Cell 53: 907-920.

Imperiale, M.J., H. Kao, L.T. Feldman, J.R. Nevins, and S. Strickland. 1984. Common control of the heat shock gene and early adenovirus genes: Evidence for a cellular Ela-like activity. Mol. Cell. Biol. 4: 867-874.

Jones, N.C., P.W.J. Rigby, and E.B. Ziff. 1988. Trans-acting protein factors and the regulation of eukaryotic transcription: Lessons from studies on DNA tumor viruses. Genes \& Dev. 2: $267-281$.

Kaddurah-Daouk, R., J.W. Lillie, G.H. Daruk, M.R. Green, R. Kingston, and P. Schimmel. 1990. Induction of cellular enzymes for energy metabolism by transforming domains of adenovirus Ela. Mol. Cell. Biol. 10: 1476-1483.

Lassar, A.B., M.J. Thayer, R.W. Overell, and H. Weintraub. 1989. Transformation by activated ras or fos prevents myogenesis by inhibitng expression of MyoDl. Cell 58: 659-667.

La Thangue, N.B. and P.W. Rigby. 1987. An adenovirus Ela-like transcription factor is regulated during the differentiation of murine embryonal carcinoma stem cells. Cell 49: 507-513.

Lillie, J.W., M. Green, and M.R. Green. 1986. An adenovirus Ela protein region required for transformation and transcriptional repression. Cell 46: 1043-1051.

Lillie, J.W., P.M. Loewenstein, M.R. Green, and M. Green. 1987. Functional domains of adenovirus type 5 Ela proteins. Cell 50: 1091-1100.

Lohse, P. and H.H. Arnold. 1988. The down-regulation of the chicken cyto-plasmic $\beta$-actin during myogenic differentiation does not require the gene promoter but involves the $3^{\prime}$ end of the gene. Nucleic Acids Res. 16: 2787-2803.

Martin, K.J., J.W. Lillie, and M.R. Green. 1990. Evidence for interaction of different eukaryotic transcriptional activators with distinct cellular targets. Nature 346: 147-152.

Miner, J.H. and B. Wold. 1990 . Herculin, a fourth member of the myoD family of myogenic regulatory genes. Proc. Nat1. Acad. Sci. 87: 1089-1093.

Moran, E., B. Zerler, T.M. Harrison, and M.B. Mathews. 1986 Identification of separate domains in the adenovirus Ela gene for immortalization activity and the activation of virus early genes. Mol. Cell. Biol. 6: 3470-3480.

Moran, E. and M.B. Mathews. 1987. Multiple functional domains in the adenovirus Ela gene. Cell 48: 177-178.

Murre, C., P.S. McCaw, and D. Baltimore. 1989a. A new DNA binding and dimerization motif in immunoglobulin enhancer binding, daughterless, MyoD and myc protein. Cell 56: 777-783.

Murre, C., P.S. McCaw, H. Vaessin, M. Caudy, L.Y. Jan, Y.N. Jan, C.V. Cabrera, J.N. Buskin, S.D. Hauschka, A.B. Lassar H. Weintraub, and D. Baltimore. 1989b. Interactions between heterologous helix-loop-helix proteins generate complexes that bind specifically to a common DNA sequence. Cell 58: 537-544.

Offringa, R., A.M.M. Smits, A. Houweling, J.L. Bos, and A.J. van der Eb. 1988. Similar effects of adenovirus Ela and glucocorticoid hormones on the expression of the metalloprotease stromelysin. Nucleic Acids Res. 16: 10973-10984.

Offringa, R., S. Gebel, H. van Dam, M. Timmers, A. Smits, R. Zwart, B. Stein, J.L. Bos, A. van der Eb, and P. Herrlich. 1990 A novel function of the transforming domain of Ela: Repression of AP-1 activity. Cell 62: 527-538.

Olson, E.N. 1990. MyoD family: A paradigm for development? Genes \& Dev. 4: 1454-1461.

Ott, M.-O., E. Bober, G. Lyons, H.H. Arnold, and M. Buckingham. 1991. Early expression of the myogenic regulatory gene, myf5, in precursor cells of skeletal muscle in the mouse embryo. Development 111: 1097-1107.

Peterson, C.A., H. Gordon, Z.W. Hall, B.M. Paterson, and H.M. Blau. 1990. Negative control of the helix-loop-helix family of myogenic regulators in the NFB mutant. Cell 62: 493502.

Piette, J., J.-L. Bessereau, M. Huchet, and J.-P. Changeux. 1990. Two adjacent MyoDl-binding sites regulate expression of the acetylcholine receptor $\alpha$-subunit gene. Nature 345: 353355.

Ptashne, M. 1988. How eukaryotic transcriptional activators work. Nature 335: 683-689.

Raychaudhuri, P., S. Bagchi, and J.R. Nevins. 1989. DNA-binding activity of the adenovirus-induced E4F transcription factor is regulated by phosphorylation. Genes \& Dev. 3: 620627.

Reich, N., R. Pine, D. Levy, and J.E. Darnell, Jr. 1988. Transcription of interferon-stimulated genes is induced by adenovirus particles but is suppressed by Ela gene products. I. Virol. 62: 114-119.

Rhodes, S.J. and S.F. Konieczny. 1989. Identification of MRF4: A new member of the muscle regulatory factor gene family. Genes \& Dev. 3: 2050-2061.

Rosenthal, N., E.B. Berglund, B.M. Wentworth, M. Donoghue, B. Winter, E. Bober, T. Braun, and H.H. Arnold. 1990. A highly conserved enhancer downstream of the human $\mathrm{MLCl} / 3$ locus is a target for multiple myogenic determination factors. Nucleic Acids Res. 18: 6239-6245.

Salminen, A., T. Braun, S. Jürs, B. Winter, A. Buchberger-Seidl, 
and H.H. Arnold. 1991. Transcription of the muscle regulatory gene MYF4 is regulated by serum mitogens, peptide growth factors, and signaling pathways involving $\mathrm{G}$ proteins. I. Cell. Biol. 115: 905-917.

Sambrook, J., E.F. Fritsch, and T. Maniatis. 1989. Molecular cloning. A laboratory manual, 2nd ed. Cold Spring Harbor Laboratory Press, Cold Spring Harbor, New York.

Sartorelli, V., K.A. Webster, and L. Kedes. 1990. Muscle-specific expression of the cardiac $\alpha$-actin gene requires MyoD1, CArG-box binding factor, and Spl. Genes \& Dev. 4: 18111822.

Sassoon, D., G. Lyons, W.E. Wright, V. Lin, A. Lassar, H. Weintraub, and M. Buckingham. 1989. Expression of two myogenic regulatory factors myogenin and $\mathrm{MyoDl}$ during mouse embryogenesis. Nature 341: 303-307.

Schäfer, B.W., B.T. Blakely, G.J. Darlington, and H.M. Blau. 1990. Effect of cell history on response to helix-loop-helix family of myogenic regulators. Nature 344: 454-458.

Schneider, J.F., F. Fischer, C.R. Goding, and N.C. Jones. 1987. Mutational analysis of the adenovirus Ela gene: The role of transcriptional regulation in transformation. EMBO $J$. 6: 2053-2060.

Simon, M.C., T.M. Fisch, B.J. Benecke, J.R. Nevins, and N. Heintz. 1988. Definition of multiple, functionally distinct TATA elements, one of which is a target in the hsp70 promoter for Ela regulation. Cell 52: 723-729.

Smith, D.B. and K.S. Johnson. 1988. Single-step purification of polypeptides expressed in Escherichia coli as fusions with glutathione S-transferase. Gene 67: 31-40.

Stein, R.W. and E.B. Ziff. 1987. Repression of insulin gene expression by adenovirus type $5 \mathrm{Ela}$ proteins. Mol. Cell. Biol. 7: 1164-1170.

Sternberg, E., G. Spizz, W.M. Perry, D. Vizard, T. Weil, and E. Olson. 1988. Identification of upstream and intragenic regulatory elements that confer cell-type-restricted and differentiation-specific expression on the muscle creatine kinase gene. Mol. Cell. Biol. 8: 2896-2909.

Subramanian, R., M. Kappuswamy, R.J. Nsar, and G. Chinnadurai. 1988. An N-terminal region of adenovirus Ela essential for cell transformation and induction of an epithelial growth factor. Oncogene 2: 105-112.

Tapscott, S.J., R.L. Davis, M.J. Thayer, P.-F. Cheng, H. Weintraub, and A.B. Lassar. 1988. MyoD1: A nuclear phosphoprotein requiring a myc homology region to convert fibroblasts to myoblasts. Science 242: 405-411.

Thayer, M.J., S.J. Tapscott, R.L. Davis, W.E. Wright, A.B. Lassar, and $\mathrm{H}$. Weintraub. 1989. Positive autoregulation of the myogenic determination gene MyoDl. Cell 58: 241-248.

Timmers, H.T.M., H. van Dam, G.J. Pronk, J.L. Bos, and A.J. van der Eb. 1989. Adenovirus Ela represses transcription of the cellular JE gene. J. Virol. 63: 1470-1473.

Velcich, A., F.G. Kern, C. Basilico, and E.B. Ziff. 1986. Adenovirus Ela proteins repress expression from polyoma virus early and late promoters. Mol. Cell. Biol. 6: 4019-4025.

Webster, K.A., G.E.O. Muscat, and L. Kedes. 1988. Adenovirus Ela products suppress myogenic differentiation and inhibit transcription from muscle-specific promoters. Nature 332: $553-557$.

Weintraub, H., S.J. Tapscott, R.L. Davis, M.J. Thayer, M.A. Adam, A.B. Lassar, and A.D. Miller. 1989. Activation of muscle specific genes in pigment, nerve, fat, liver and fibroblast cell lines by forced expression of MyoD. Proc. Natl. Acad. Sci. 86: 5434-5438.

Weintraub, H., V.J. Dwarki, I. Verma, R. Davis, S. Hollenberg, L. Snider, A. Lassar, and S.J. Tapscott. 1991. Muscle-specific transcriptional activation of MyoD. Genes \& Dev. 5: 1377-
1386.

Whyte, P., H.E. Ruley, and E. Harlow. 1988. Two regions of the adenovirus Ela proteins are required for transformation. $J$. Virol. 62: 257-265.

Winter, B., T. Braun, and H.H. Arnold. 1992. Co-operativity of functional domains in the muscle-specific transcription factor Myf-5. EMBO I. 11 (in press).

Wright, W.E., D.A. Sassoon, and V.K. Lin. 1989. Myogenin, a factor regulating myogenesis, has a domain homologous to MyoD1. Cell 56: 607-617.

Yaffe, D. 1968. Retention of differentiation potentialities during prolonged cultivation of myogenic cells. Proc. Natl. Acad. Sci. 61: 477-483.

Yee, A.S., P. Raychaudhuri, L. Jakoi, and J.R. Nevins. 1989. The adenovirus-inducible factor E2F stimulates transcription after specific DNA binding. Mol. Cell. Biol. 9: 578-585.

Yutzey, K.E., S.J. Rhodes, and S.F. Konieczny. 1990. Differential trans-activation associated with the muscle regulatory factors MyoDl, myogenin and MRF4. Mol. Cell. Biol. 10: 39343944.

Zerler, B., B. Moran, K. Maruyama, J. Moomaw, T. Grodzicker, and H.E. Ruley. 1986. Adenovirus Ela coding sequences that enable ras and pmt oncogenes to transform cultured primary cells. Mol. Cell. Biol. 6: 887-899. 


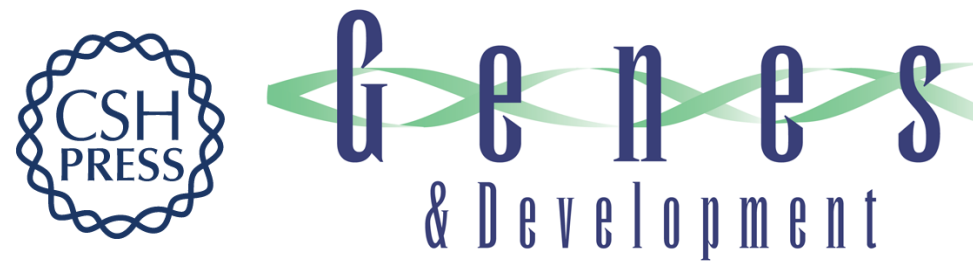

\section{Inhibition of muscle differentiation by the adenovirus E1a protein: repression of the transcriptional activating function of the $\mathrm{HLH}$ protein Myf-5.}

T Braun, E Bober and $\mathrm{H} \mathrm{H}$ Arnold

Genes Dev. 1992, 6:

Access the most recent version at doi:10.1101/gad.6.5.888

References This article cites 71 articles, 35 of which can be accessed free at: http://genesdev.cshlp.org/content/6/5/888.full.html\#ref-list-1

License

Email Alerting Service

Receive free email alerts when new articles cite this article - sign up in the box at the top right corner of the article or click here.

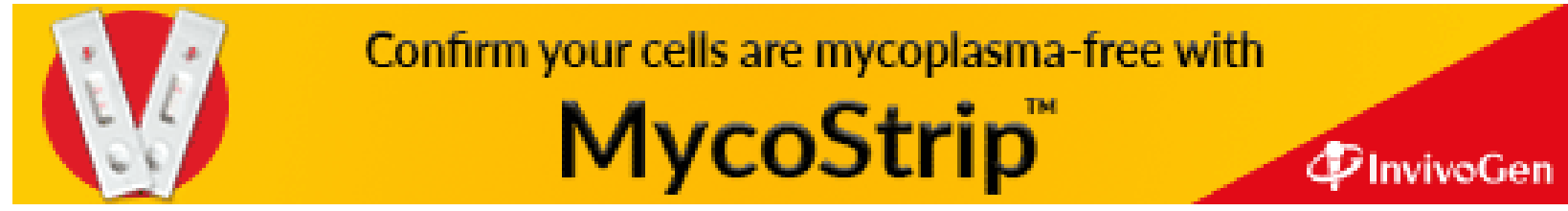

